\title{
Cholesterol Metabolism
}

\section{CHOLESTEROL METABOLISM IN THE GUINEA PIG AND RABBIT}

\author{
- By R. P. COOK AND R. O. THOMSON \\ Department of Biochemistry, University College, Dundee (University of St Andrews)
}

(Received 6 September 1950)

Experiments on the metabolism of cholesterol in rats fed chemically defined and animal-cake diets were reported previously (Cook, Polgar \& Thomson, 1950). Guinea pigs and rabbits do not consume the synthetic diet readily, but the animal cake is taken well. The experiments reported here are on the metabolism of cholesterol in guinea pigs and rabbits fed a basal ration of animal cake. Balance sheets of the cholesterol have been made, which are compared with those obtained with rats on the animal-cake diet. It is true that numerous balance experiments have been carried out on various animal species (for review see Cook, 1942-3). The general conclusion to be drawn is that when excess cholesterol is fed there is a loss of sterol.

The experiments to be described demonstrate some of the species differences in cholesterol metabolism on basal diets of essentially the same composition. It is to be stressed that the chemical findings are of a preliminary nature. The analytical methods used give, however, gravimetric values for neutral and acidic fractions. Specific methods for dealing with the components of these fractions are being developed.

\section{METHODS}

Animals. (a) Guinea pigs. Male animals about 6 months old and of average weight $400 \mathrm{~g}$. were used. (b) Rabbits. Male Dutch rabbits about 6 months old and of average weight $1.4 \mathrm{~kg}$. were selected. Both species were obtained locally. Litter mates were used for each set of experiments, the animals being placed in metabolism cages in a room maintained at a temperature of $22^{\circ} \pm 1^{\circ}$. Other particulars are given by Cook et al. (1950).

Diet. The basal diet consisted of rat cake (North-Eastern Agriculture Co-operative Society Ltd., Aberdeen) and contained $5 \%$ ether-soluble lipid and $12 \mathrm{mg}$. sterol/100 g. To this was added olive oil (obtained locally) in the proportion of $200 \mathrm{~g}$. oil/kg. rat cake. When cholesterol was added $20 \mathrm{~g}$. were mixed in the warm oil on a water bath, and when dissolved the mixture was added to the rat cake. The diet of the animals was supplemented with $10 \mathrm{mg}$. ascorbic acid and $50 \mathrm{~g}$. fresh savoy leaves daily.

Extraction of faecal lipid. The methods used for extraction of lipid and for fractionation have been described by Cook et al. (1950). The faeces were not further extracted with ethanol. The results are, however, comparable.

Free fatty acids. Faecal lipids (100 mg.) were dissolved in $20 \mathrm{ml}$. absolute ethanol and the solution titrated in the cold with $0 \cdot 1 \mathrm{~N}$-ethanolic $\mathrm{KOH}$. The free acid was calculated as of equivalent 284.

Livers. Pooled liver samples were used and analysed as described by Cook et al. (1950).

Carcasses and gut. At the end of an experiment, the carcasses and gut of the guinea pigs were pooled, digested for $6 \mathrm{hr}$. with $10 \%$ (w/v) ethanolic $\mathrm{KOH}$, made up to volume and a sample acidified and extracted with ether. The extracted lipid was then fractionated into unsaponifiable matter and the total sterol estimated. With the rabbits the same procedure was adopted, but the carcasses and gut were analysed separately.

Urine. The total volume of urine collected throughout certain experiments was measured. A sample was strongly acidified with conc. $\mathrm{HCl}$ and extracted with 1 vol. of ether divided into three portions. The value given for lipid is the ether-soluble material.

Free and total sterol. Total sterol was determined by the method of Schoenheimer \& Sperry (1934) on the lipid from the faeces, carcasses and/or gut, and urine. Free sterol was determined on the faecal lipids.

\section{RESULTS}

The duration of experiment, weights of animals, total food, fat and cholesterol ingested are shown in Table 1. For continuity the serial numbers used previously have been continued. The guinea pigs in Exp. IX, S group, did not eat the diet readily and took 14 days longer to consume the same amount of food as did the control animals. The increase in weight of the cholesterol-fed animals was only slight as compared with that of the control animals. In Exp. $X$ approximately the same amount of food was consumed by both series of animals in the same time, but the animals in both series lost weight, the effect being most marked in Exp. $X, S$ group.

In the rabbit experiments three animals were used initially in both groups, but at the end of 58 days one of the cholesterol-fed animals died. The experiment was continued with two animals in each group. During the first period (XI) the cholesterol-fed animals took the diet well and increased in weight, but during the second period (XII, S group) the intakes of food were poor and the animals steadily lost weight. The bodies of the cholesterol-fed animal which died after 58 days and of the third control animal were retained for analysis. 
Table 1. Duration of experiment, weights of animals, total food, fat and added cholesterol ingested (In this and subsequent tables $\mathrm{C}=$ control group, $\mathrm{S}=$ group fed diet plus cholesterol.)

\begin{tabular}{|c|c|c|c|c|c|c|c|}
\hline Animals & $\begin{array}{c}\text { Exp. } \\
\text { no. }\end{array}$ & $\begin{array}{l}\text { No. of } \\
\text { animals }\end{array}$ & $\begin{array}{c}\text { Increase or } \\
\text { decrease in } \\
\text { wt. during } \\
\text { experiment } \\
\text { (g.) }\end{array}$ & $\begin{array}{c}\text { Duration } \\
\text { of experiment } \\
\text { (days) }\end{array}$ & $\begin{array}{l}\text { Total } \\
\text { food } \\
\text { (g.) }\end{array}$ & $\begin{array}{l}\text { Fat } \\
\text { (g.) }\end{array}$ & $\begin{array}{l}\text { Added } \\
\text { cholesterol } \\
\text { (g.) }\end{array}$ \\
\hline Guinea pigs & $\begin{aligned} \text { IX C } \\
\text { IX S } \\
\text { X C } \\
\text { X S }\end{aligned}$ & $\begin{array}{l}2 \\
2 \\
2 \\
2\end{array}$ & $\begin{array}{r}+247 \\
+\quad 26 \\
-\quad 127 \\
-\quad 223\end{array}$ & $\begin{array}{l}30 \\
44 \\
34 \\
34\end{array}$ & $\begin{array}{l}1060 \\
1070 \\
1230 \\
1105\end{array}$ & $\begin{array}{l}177 \\
175 \\
205 \\
181\end{array}$ & $\begin{array}{c}0 \\
17 \cdot 6 \\
0 \\
18 \cdot 1\end{array}$ \\
\hline Rabbits & $\begin{array}{r}\text { XI C } \\
\text { XI S } \\
\text { XII C } \\
\text { XII S }\end{array}$ & $\begin{array}{l}3 \\
3 \\
2 \\
2\end{array}$ & $\begin{array}{l}+2170 \\
+2271 \\
+\quad 220 \\
-\quad 720\end{array}$ & $\begin{array}{l}58 \\
58 \\
18 \\
19\end{array}$ & $\begin{array}{r}6080 \\
6680 \\
1650 \\
450\end{array}$ & $\begin{array}{r}1015 \\
1095 \\
275 \\
74\end{array}$ & $\begin{array}{c}0 \\
109 \cdot 5 \\
0 \\
7 \cdot 4\end{array}$ \\
\hline
\end{tabular}

Table 2. Faecal excretion of guinea pigs and rabbits

(In this and subsequent tables, -, means 'not determined'.)

\begin{tabular}{|c|c|c|c|c|c|c|c|}
\hline Animals & $\begin{array}{c}\text { Exp. } \\
\text { no. }\end{array}$ & $\begin{array}{l}\text { Wt. } \\
\text { faeces } \\
\text { (g.) }\end{array}$ & $\begin{array}{l}\text { Ether- } \\
\text { soluble } \\
\text { lipid } \\
\text { (g.) }\end{array}$ & $\begin{array}{l}\text { Unsaponifiable } \\
\text { matter (U.M.) } \\
\text { (g.) }\end{array}$ & $\begin{array}{l}\text { Total } \\
\text { sterol } \\
\text { (g.) }\end{array}$ & $\begin{array}{l}\text { Total } \\
\text { acids } \\
\text { (g.) }\end{array}$ & $\begin{array}{c}\text { Light } \\
\text { petroleum- } \\
\text { insoluble acids } \\
\text { (g.) }\end{array}$ \\
\hline \multirow[t]{3}{*}{ Guinea pigs } & $\begin{array}{l}\text { IX C } \\
\text { IX S }\end{array}$ & $\begin{array}{l}236 \\
367\end{array}$ & $\begin{array}{l}36 \cdot 3 \\
76 \cdot 8\end{array}$ & $\begin{array}{r}9 \cdot 6 \\
19 \cdot 3\end{array}$ & $\begin{array}{l}0 \cdot 8 \\
5 \cdot 2\end{array}$ & $\begin{array}{l}20 \cdot 9 \\
48 \cdot 5\end{array}$ & - \\
\hline & X C & 315 & $53 \cdot 5$ & $5 \cdot 8$ & $1 \cdot 2$ & $40 \cdot 5$ & 0.22 \\
\hline & X S & 328 & $70 \cdot 3$ & $17 \cdot \tilde{5}$ & $9 \cdot 4$ & $44 \cdot 2$ & $0 \cdot 34$ \\
\hline \multirow[t]{4}{*}{ Rabbits } & $\begin{array}{l}\text { XI C } \\
\text { XIS }\end{array}$ & 1289 & $\begin{array}{r}80 \cdot 4 \\
34 \cdot 0\end{array}$ & $14 \cdot 9$ & $4 \cdot 1$ & $57 \cdot \tilde{5}$ & $6 \cdot 7$ \\
\hline & XIS & 1335 & $134 \cdot 0$ & $63 \cdot 1$ & $25 \cdot 2$ & $63 \cdot 7$ & $3 \cdot 0$ \\
\hline & XII C & 302 & $15 \cdot 5$ & $2 \cdot 8$ & $0 \cdot 9$ & $9 \cdot 7$ & - \\
\hline & XII S & 141 & 14.6 & $4 \cdot 6$ & $2 \cdot 4$ & $7 \cdot 1$ & - \\
\hline
\end{tabular}

In Table 2 are given the values for the excretion of faecal lipids. In these experiments the ether-soluble lipid only was investigated, no further extraction with ethanol being carried out. The data, therefore, with respect to the total acids and particularly the light petroleum-insoluble acids are not complete. They are, however, directly comparable.

The unsaponifiable matter (U.M.) and total sterol were increased in amount in both species after cholesterol feeding. With the guinea pigs in Exp. IX there was a large increase in the total acids excreted after cholesterol feeding, but this difference was not so marked in Exp. X. It is possible that the longer duration of Exp. IX, S group, affected the absorption of fat. Guinea pigs do not take readily to a diet rich in fat, and the experiments could not be continued for as long as the rabbit experiments. With the rabbits (Exp. XI) the increase in excretion of total acids after cholesterol feeding was slight compared with the amount of cholesterol fed, and in Exp. XII there was a decrease in the excretion of acids.

Determinations of the light petroleum-insoluble acids were not done in all experiments but with the guinea pigs there was a slight increase after cholesterol feeding. With the rabbits a large amount was present in the faecal acids of the control animals, but the amount was decreased after cholesterol feeding.
The species difference in excretion is better illustrated by the values for the faecal components as percentages of the total ether-soluble lipid. These are shown in Table 3 where the values for the faecal lipids of rats (Exp. VI, Cook et al. 1950) have been added for comparison. In all species after the feeding of cholesterol the U.M. as percentage of lipid increased in amount, as did the total sterol. The sterol as percentage of U.M. was greatest with the rat and least with the rabbit. The percentage of ester sterol was lowest with the guinea pigs and highest with the rat. Total fatty acids were of the same order in the faeces of the control animals but the percentage fell after cholesterol feeding due to dilution by U.M. An interesting feature is the high percentage of free fatty acids excreted by the guinea pig. The light petroleuminsoluble acids formed a low percentage of the acids in both control and cholesterol-fed guinea pigs, but there was an increase with the latter animals. In the rabbit these acids formed a high percentage of the faecal acids of the control animals, but after cholesterol feeding the percentage fell. The high proportion of light petroleum-insoluble acids and its increase after cholesterol feeding in the rats has already been noted.

The urinary excretion values for certain experiments are given in Table 4 and are incomplete. They do demonstrate that there was a slight additional excretion of lipid in the urine of the guinea pigs, and 
Table 3. Distribution of faecal lipids

(Values as percentage of ether-soluble lipid, except where stated otherwise.)

U.M.

Total sterol

Ester sterol

Total fatty acids

Free fatty acids

Light petroleum-insoluble acids

Sterol as \% U.M.

Ester as \% total sterol

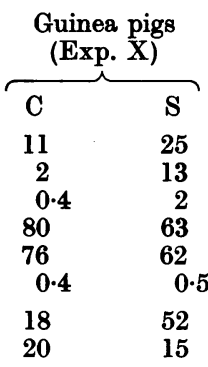

\begin{tabular}{|c|c|}
\hline \multicolumn{2}{|c|}{$\begin{array}{c}\text { Rats } \\
\text { (Exp. VI) }\end{array}$} \\
\hline C & $\mathbf{S}$ \\
\hline 19 & 55 \\
\hline 9 & 37 \\
\hline 4 & 9 \\
\hline 61 & 41 \\
\hline 30 & 26 \\
\hline 6 & 7 \\
\hline 47 & 67 \\
\hline 44 & 24 \\
\hline
\end{tabular}

Table 4. Urinary excretion

$\begin{array}{ccccc}\text { Animals } & \text { Exp. } & \text { Volume } & \text { Total lipid } & \text { Total sterol } \\ \text { Guinea pigs } & \text { no. } & (\text { (l.) } & \text { (g.) } & - \\ & \text { IX C } & 1 \cdot 46 & 0.7 & - \\ \text { Rabbits } & \text { IX S } & 1 \cdot 12 & 1 \cdot 2 & -12 \\ & \text { XI C } & 18.9 & 20.9 & 80 \\ & \text { XI S } & 17.6 & 33 \cdot 6 & 210\end{array}$

Table 5. Values for livers

\begin{tabular}{|c|c|c|c|c|c|c|c|c|c|}
\hline \multirow[b]{2}{*}{ Animals } & \multirow[b]{2}{*}{$\begin{array}{c}\text { Exp. } \\
\text { no. }\end{array}$} & \multirow[b]{2}{*}{$\begin{array}{l}\text { No. of } \\
\text { livers }\end{array}$} & \multirow[b]{2}{*}{$\begin{array}{l}\text { Wt. } \\
\text { (g.) }\end{array}$} & \multirow[b]{2}{*}{$\begin{array}{c}\text { Livers } \\
\text { (as \% } \\
\text { body wt.) }\end{array}$} & \multirow{2}{*}{$\begin{array}{c}\text { Lipid } \\
\text { (as \% } \\
\text { fresh } \\
\text { liver wt.) }\end{array}$} & \multicolumn{2}{|c|}{ U.M. } & \multicolumn{2}{|c|}{ Total sterol } \\
\hline & & & & & & (g.) & $\begin{array}{l}\text { (as \% } \\
\text { lipid) }\end{array}$ & (g.) & $\begin{array}{l}\text { (as \% } \\
\text { lipid) }\end{array}$ \\
\hline Guinea pigs & $\begin{array}{r}\text { IX C } \\
\text { IX S } \\
\mathbf{X} \mathbf{C} \\
\mathbf{X} \mathbf{S}\end{array}$ & $\begin{array}{l}2 \\
2 \\
2 \\
2\end{array}$ & $\begin{array}{l}\mathbf{3 5 \cdot 4} \\
\mathbf{7 6 \cdot 7} \\
\mathbf{4 4} \cdot 8 \\
\mathbf{5 6} \cdot 5\end{array}$ & $\begin{array}{r}4 \cdot 1 \\
10 \cdot 2 \\
4 \cdot 2 \\
6 \cdot 9\end{array}$ & $\begin{array}{r}7 \cdot 1 \\
18 \cdot 8 \\
5 \cdot 9 \\
15 \cdot 2\end{array}$ & $\begin{array}{l}0 \cdot 15 \\
2 \cdot 25 \\
0 \cdot 3 \\
1 \cdot 7\end{array}$ & $\begin{array}{r}6 \cdot 0 \\
15 \cdot 6 \\
10 \cdot 0 \\
19 \cdot 8\end{array}$ & $\begin{array}{l}0.1 \\
1.6 \\
1.2\end{array}$ & $\begin{array}{r}4 \cdot 0 \\
11 \cdot 0 \\
\frac{13.4}{13}\end{array}$ \\
\hline Rabbits & $\begin{array}{r}\text { XI C } \\
\text { XI S } \\
\text { XII S }\end{array}$ & $\begin{array}{l}3 \\
1^{*} \\
2 \dagger\end{array}$ & $\begin{array}{r}138 \cdot 6 \\
90 \cdot 3 \\
247 \cdot 3\end{array}$ & $\begin{array}{l}3 \cdot 4 \\
7 \cdot 7 \\
8 \cdot 6\end{array}$ & $\begin{array}{r}6 \cdot 3 \\
19 \cdot 7 \\
20 \cdot 4\end{array}$ & $\begin{array}{r}0.8 \\
7 \cdot 2 \\
21 \cdot 9\end{array}$ & $\begin{array}{l}10 \cdot 3 \\
40 \cdot 4 \\
43 \cdot 5\end{array}$ & $\begin{array}{r}0 \cdot 6 \\
5 \cdot 3 \\
16 \cdot 7\end{array}$ & $\begin{array}{r}6 \cdot 9 \\
29 \cdot 8 \\
33 \cdot 2\end{array}$ \\
\hline Rats & $\begin{array}{l}\text { VIII C } \\
\text { VIII S }\end{array}$ & 2 & $\begin{array}{l}19.6 \\
40.5\end{array}$ & $\begin{array}{l}2 \cdot 9 \\
5 \cdot 5\end{array}$ & $\begin{array}{r}7 \cdot 9 \\
17 \cdot 3\end{array}$ & $\begin{array}{l}0 \cdot 1 \\
2 \cdot 1\end{array}$ & $\begin{array}{r}7 \cdot 0 \\
30 \cdot 6\end{array}$ & $\begin{array}{l}0.1 \\
1.8\end{array}$ & $\begin{array}{r}5 \cdot 7 \\
25 \cdot 0\end{array}$ \\
\hline
\end{tabular}

that with the rabbits, although the amount of lipid was increased after cholesterol feeding, the increased excretion of sterol was slight. The nature of the urinary lipids in guinea pigs and rabbits will be investigated later.

In Table 5 are given the values for the liver lipids. In Exp. IX and $X$ two livers were pooled and analysed. In Exp. XI, C group, three livers were pooled, but the value for Exp. XI, S group, is for the liver of the animal which died after 58 days. In Exp. XII, S group, two livers were pooled. The large increase in size of the guinea pig liver after cholesterol feeding, particularly in Exp. IX, S group, is noteworthy. The percentage of lipid increased twoto three-fold, and the U.M. and sterol constituted as mean values 18 and $12 \%$ respectively of the lipid.

In the rabbit there was an increase in size of the liver and an increase in the percentage of lipid, but the most striking increase as compared with the guinea pig was in the amount of U.M. and of sterol
(42 and $32 \%$ respectively of the lipid). The values for rat livers are given for comparison and appear to be intermediate between those for the guinea pig and rabbit.

Analysis of the carcasses and gut are given in Table 6. With the guinea pigs the two parts were analysed together and the results shown are for two pooled animals in each experiment. With the rabbit, carcasses and gut were dealt with separately. For the control group three animals were pooled. In the cholesterol-fed group, the carcass and gut of the animal that had died after 58 days was. pooled and analysed with the two animals in Exp. XII. The amount of lipid in the carcasses and/or gut of the animals fed cholesterol was much less than with the control animals. This confirmed the visual observation that the cholesterol-fed animals had poor fat depots. This effect of cholesterol on the depot fats of rats is seen only in experiments of duration greater than 60 days (Cook, 1936, 1937). 'The amount of 
Table 6. Analyses of carcasses and gut

(All results in g.)

\begin{tabular}{|c|c|c|c|c|c|c|c|c|}
\hline & \multirow{2}{*}{$\begin{array}{c}\text { Exp. } \\
\text { no. }\end{array}$} & \multicolumn{4}{|c|}{ Carcass } & \multicolumn{3}{|c|}{ Gut } \\
\hline & & Wt. & Lipid & U.M. & Sterol & Lipid & U.M. & Sterol \\
\hline Guinea pigs & $\begin{array}{r}\text { IX C } \\
\text { IX S } \\
\mathbf{X} \\
\mathbf{X} \\
\mathbf{C}\end{array}$ & $\begin{array}{l}846 \\
677 \\
950 \\
720\end{array}$ & $\begin{array}{l}41 \cdot 7 \\
29: 0 \\
46 \cdot 8 \\
24 \cdot 6\end{array}$ & $\begin{array}{l}1 \cdot 1 \\
2 \cdot 2 \\
1 \cdot 4 \\
2 \cdot 7\end{array}$ & $\begin{array}{l}0.7 \\
1.4 \\
1.4\end{array}$ & \multicolumn{3}{|c|}{$\begin{array}{l}\text { Included in carcass } \\
\text { Included in carcass } \\
\text { Included in carcass } \\
\text { Included in carcass }\end{array}$} \\
\hline Rabbits & $\begin{array}{l}\text { C } \\
\text { S }\end{array}$ & $\begin{array}{l}3160 \\
2772\end{array}$ & $\begin{array}{l}388.0 \\
181 \cdot 3\end{array}$ & $\begin{array}{r}7 \cdot 4 \\
15 \cdot 6\end{array}$ & $\begin{array}{r}3 \cdot 8 \\
11 \cdot 6\end{array}$ & $\begin{array}{l}42 \cdot 5 \\
33 \cdot 2\end{array}$ & $\begin{array}{l}2 \cdot 0 \\
4 \cdot 3\end{array}$ & $\begin{array}{l}1 \cdot 0 \\
2 \cdot 1\end{array}$ \\
\hline
\end{tabular}

Table 7. Unsaponifiable matter (U.M.) balance of the various species

(The differences in U.M. content of the ether-extractable lipid of the cholesterol-fed and control animals for faeces, livers, carcasses and/or gut are given. The sum $A$ represents total U.M. accounted for and $B$ the amount of ingested cholesterol. $B-A$ is the amount of cholesterol (as g.) unaccounted for, this value being shown also as \%. The values for the increase in total faecal acids and light petroleum-insoluble acids are given in the last two lines. The values for the rats are from Cook et al. (1950).)

\begin{tabular}{|c|c|c|c|c|c|c|}
\hline & \multirow[b]{2}{*}{ Exps. } & \multicolumn{2}{|c|}{ Guinea pigs } & \multirow{2}{*}{$\underset{\text { XII }}{\text { Rabbits }}$} & \multicolumn{2}{|c|}{ Rats } \\
\hline & & IX & $\mathbf{X}$ & & VI & VIII \\
\hline Difference (g.) of U.M. in & $\left\{\begin{array}{l}\text { Faeces } \\
\text { Livers } \\
\text { Carcasses } \\
\text { Gut }\end{array}\right.$ & $\begin{array}{l}9 \cdot 7 \\
2 \cdot 1 \\
1 \cdot 1 \\
-\end{array}$ & $\begin{array}{r}11 \cdot 7 \\
1 \cdot 4 \\
1 \cdot 3 \\
-\end{array}$ & $\begin{array}{r}50 \cdot 0 \\
28 \cdot 3 \\
8 \cdot 2 \\
2 \cdot 3\end{array}$ & $\begin{array}{r}13 \cdot 9 \\
1 \cdot 0 \\
-\end{array}$ & $\begin{array}{r}16 \cdot 8 \\
2 \cdot 1 \\
-\end{array}$ \\
\hline Total, $A$ (g.) & & $12 \cdot 9$ & $14 \cdot 4$ & $88 \cdot 8$ & $14 \cdot 9$ & $18 \cdot 9$ \\
\hline $\begin{array}{l}\text { Cholesterol fed, } B \text { (g.) } \\
\text { Cholesterol unaccounted } \\
\text { Cholesterol unaccounted } \\
\text { Increase in total faecal fa } \\
\text { Increase in light petroleu }\end{array}$ & $\begin{array}{l}\text { or }(B-A) \text { (g.) } \\
\text { or (as \% of amount fed) } \\
\text { tty acids (g.) } \\
\text { m-insoluble acids (g.) }\end{array}$ & $\begin{array}{c}17 \cdot 6 \\
4 \cdot 7 \\
27 \\
27 \cdot 6 \\
-\end{array}$ & $\begin{array}{c}18 \cdot 1 \\
3 \cdot 7 \\
20 \\
3 \cdot 7 \\
0 \cdot 1\end{array}$ & $\begin{array}{c}116 \cdot 9 \\
28 \cdot 1 \\
24 \\
3 \cdot 6^{*} \\
-3 \cdot 7^{*}\end{array}$ & $\begin{array}{r}18 \cdot 9 \\
4 \cdot 0 \\
21 \\
5 \cdot 6 \\
1 \cdot 5\end{array}$ & $\begin{array}{c}22 \cdot 1 \\
3 \cdot 2 \\
14 \\
9 \cdot 1 \\
1 \cdot 0\end{array}$ \\
\hline
\end{tabular}

Table 8. Total sterol balance of the various species

(The differences in sterol content of the ether-extractable lipid of the cholesterol-fed and control animals are given.)

\begin{tabular}{|c|c|c|c|c|c|}
\hline & & & & & \\
\hline Exps. & $\ldots$ & IX & $\mathbf{X}$ & $\begin{array}{c}\text { Rabbits } \\
\text { XII }\end{array}$ & $\begin{array}{c}\text { Rats } \\
\text { VI }\end{array}$ \\
\hline Difference (g.) of total sterol in & $\begin{array}{l}\text { Faeces } \\
\text { Livers } \\
\text { Carcasses } \\
\text { Gut }\end{array}$ & $\begin{array}{l}4 \cdot 4 \\
1 \cdot 5 \\
0 \cdot 7 \\
-\end{array}$ & $\begin{array}{l}8 \cdot 2 \\
1 \cdot 2 \\
0 \cdot 7 \\
-\end{array}$ & $\begin{array}{r}22 \cdot 6 \\
21 \cdot 4 \\
7 \cdot 8 \\
2 \cdot 3\end{array}$ & $\begin{array}{l}9 \cdot 7 \\
0 \cdot 9 \\
- \\
-\end{array}$ \\
\hline Total, $A$ (g.) & & $6 \cdot 6$ & $10 \cdot 1$ & $54 \cdot 1$ & $10 \cdot 6$ \\
\hline $\begin{array}{l}\text { Cholesterol fed, } B \text { (g.) } \\
\text { Cholesterol unaccounted for ( } B \\
\text { Cholesterol unaccounted for (as }\end{array}$ & $\begin{array}{l}-A \text { ) (g.) } \\
\% \text { of amount fed) }\end{array}$ & $\begin{array}{l}17 \cdot 6 \\
11 \cdot 0 \\
63\end{array}$ & $\begin{array}{r}18 \cdot 1 \\
8 \cdot 0 \\
44\end{array}$ & $\begin{array}{c}116 \cdot 9 \\
62 \cdot 8 \\
54\end{array}$ & $\begin{array}{l}18 \cdot 9 \\
8 \cdot 3 \\
44\end{array}$ \\
\hline
\end{tabular}

U.M. and of sterol was increased slightly in the carcasses and gut of the guinea pigs, but large amounts were present in the cholesterol-fed rabbits. There would appear to be a generalized deposition of cholesterol in this animal (Aylward \& Stott, 1937).

In the rat the deposition of cholesterol in the carcass was slight and may be neglected in constructing a balance sheet (Cook, 1937).

From the results given in Tables 2, 5, and 6 it is possible to construct balance sheets of the sterol metabolism both on the differences in U.M. content in cholesterol-fed and control animals, and on the difference in sterol content. The values for the urinary excretion have been omitted as they are incomplete, but the error so introduced is slight. Balance sheets based on the U.M. are shown in Table 7 where values for certain experiments on the rat (Cook et al. 1950) are given. The results for the guinea pigs show that there is a mean loss of $24 \%$ of the ingested cholesterol. In Exp. IX there was a large increase in the excretion of total fatty acids, but in Exp. $X$ the increase was equal in amount to the missing cholesterol. Determinations of the light petroleum-insoluble acids were not carried out in Exp. IX, but the increase in Exp. $X$ was slight. With rabbits there is a $24 \%$ loss of cholesterol but only a 
slight increase in the excretion of total faecal acids. The difference between the light petroleum-insoluble acids is actually negative, i.e. more acids are produced by the control animals.

The results with rats are shown for comparison and give a mean loss of $18 \%$ cholesterol. The increase in total faecal acid and its correspondence with the missing cholesterol have been commented on before. The rat shows the greatest production of light petroleum-insoluble acids on the cholesterolcontaining diet.

Balance sheets from certain experiments based on the differences in sterol content are given in Table 8 . With guinea pigs the mean loss of cholesterol as a difference between the cholesterol-fed and control animals is $54 \%$ of that ingested, with rabbits $54 \%$ and the value for the rat is $44 \%$. These values are greater than those obtained for U.M. difference, and indicate that part of the cholesterol is converted into compounds which appear in the U.M. (cf. Page \& Menschick, 1932; Bossert, Page \& Menschick, 1934).

It is interesting to observe that, whether based on loss of U.M. or of sterol, there would appear to be a greater percentage loss of cholesterol in the guinea pig and rabbit than there is the rat. The rat, however, produces excess faecal fatty acids which correspond to the loss of cholesterol and these acids contain a high percentage of light petroleum-insoluble acids.

\section{DISCUSSION}

The reactions of the rat, guinea pig and rabbit to the presence of large amounts of cholesterol in the diet are very different. Rats can apparently tolerate large amounts of dietary cholesterol, and although they develop 'fatty' livers, suffer little inconvenience. The guinea pigs and rabbits are affected very adversely. The guinea pigs lose weight and develop greatly enlarged 'fatty' livers and spleens. The rabbits for a time grow and maintain weight, but later there is a loss of appetite and weight.

The ingestion of cholesterol causes a generalized lipid deposition including deposition of cholesterol and its esters in the intima of the aorta, giving rise to the pathological picture of atheroma. The pathological changes observed in rats, guinea pigs and rabbits are described in detail by Cook \& McCullagh (1939).

Okey \& Greaves (1939) also described the development of a marked anaemia in guinea pigs. Experiments with other animals are reviewed by Cook (1942-3). The question arises as to how these different reactions are related to the metabolism of cholesterol.

The absorption of fat (olive oil) and of cholesterol in the rat, guinea pig and rabbit is described in detail by Cook \& Thomson (1950). On the animal rat-cake diet containing $16.6 \%$ fat the following absorptions of fat (as \%) were observed: rat, 92; guinea pig, 77 and rabbit 94 . With fat and $1.6 \%$ cholesterol the cholesterol absorptions (measured as U.M.) were (as \%) rat 34 , guinea pig 47 , and rabbit 77 . The absorption of fat by the guinea pig is thus less than with the other species, but the order of cholesterol absorption is rat, guinea pig, rabbit. This order is reflected in the levels of plasma cholesterol obtained which in the rabbit may reach values as high as $2000 \mathrm{mg}$. $/ 100 \mathrm{ml}$. (Cook \& Thomson, 1950). One possibility, therefore, is that the species difference is due to the fact that absorption occurs more readily in some species than others (cf. rat and rabbit).

The relation of the excretion of faecal acids to the absorption process is not clear, but while there is a considerable excretion of excess acids in the cholesterol-fed guinea pigs and rats, the increase was slight with the rabbits in Exp. XI, and in Exp. XII there was a decrease. The overall excretion of acids corresponded to $15 \%$ of the missing cholesterol. It is probable that there is some connexion between the absorption of cholesterol and the excretion of acids. Experiments on the rat show that cholesterol hinders the absorption of fat and that in cholesterol-fed animals there is an increased excretion of ordinary fatty acids (Edwards \& Cook, 1951). Acetic acid and other volatile acids were also increased in amount (Thomson, 1951).

That cholesterol is broken down is certain and in the rat part of the degradation products appear in the light petroleum-insoluble fraction. The results given here show that the cholesterol-fed guinea pigs have a slightly increased production of light petroleum-insoluble acids, but the rabbit is different in that greater amounts are produced with the control animals than with those fed cholesterol.

The experiments of Schoenheimer \& Breusch (1933) demonstrated that in mice fed normal diets there was a balance between cholesterol synthesis and destruction. This may well be true of other species, but when excess cholesterol is fed, as in the experiments described here, degradation exceeds synthesis. The pathways of degradation are numerous and may result in the production of neutral products such as coprostanol, which would appear in the unsaponifiable matter fraction, or in the production of acidic compounds. The complete identification of the products of metabolism will be a lengthy procedure.

One conclusion at least is clear from the experiments described here, which is that there is a marked species difference in response to the inclusion of excess cholesterol in the diet.

\section{SUMMARY}

1. Guinea pigs and rabbits were fed a basal diet of animal cake and $16.6 \%$ olive oil with and without $1.6 \%$ cholesterol. The faecal excretion of lipid and its deposition in the tissues were studied. 
2. The ether-soluble faecal lipids were fractionated into unsaponifiable matter, total sterol, total acids and light petroleum-insoluble acids (Table 2). The distribution of the faecal lipids was determined (Table 3).

3. The deposition of unsaponifiable matter and sterol in the livers, carcasses and gut was determined (Tables 5 and 6).

4. Balance sheets of the cholesterol metabolism have been made both on differences in unsaponifiable matter (Table 7) and the differences in sterol (Table 8) between cholesterol-fed and control animals. Calculated as unsaponifiable matter an average of $24 \%$ of the cholesterol ingested was metabolized in guinea pigs and in rabbits (one experiment) $24 \%$. As sterol the guinea pigs and rabbits metabolized $54 \%$. For rats these values are, unsaponifiable matter, $18 \%$ and sterol $44 \%$.

5. In guinea pigs there was an increased excretion of total faecal fatty acids in the cholesterol-fed animals. In the rabbit this increase is slight.

The light petroleum-insoluble acids were slightly increased in the faeces of cholesterol-fed guinea pigs, but in the rabbit more light petroleum-insoluble acids are present in the faeces of control animals than there are in those fed cholesterol.

6. The significance of these findings in relation to the pathological lesions produced in these different species by feeding excess cholesterol in this diet is discussed.

We are greatly indebted to the Medical Research Council for a personal grant to R. 0 . T. and a grant for expenses.

\title{
REFERENCES
}

Aylward, F. X. \& Stott, W. (1937). Biochem. J. 31, 2055. Bossert, K., Page, I. H. \& Menschick, W. (1934). Biochem. Z. 268, 93.

Cook, R. P. (1936). Biochem. J. 30, 1630.

Cook, R. P. (1937). Biochem. J. 31, 410.

Cook, R. P. (1942-3). Nutr. Abstr. Rev. $12,1$.

Cook, R. P. \& McCullagh, G. P. (1939). Quart.J.exp. Physiol. 29, 283.

Cook, R. P., Polgar, N. \& Thomson, R. O. (1950). Biochem. J. 47, 600 .
Cook, R. P. \& Thomson, R. O. (1950). Quart. J. exp. Physiol. 36, 61 .

Edwards, D. C. \& Cook, R. P. (1951). Biochem. J. 48, ix.

Okey, R. \& Greaves, V. D. (1939). J. biol. Chem. 129, 111.

Page, I. H. \& Menschick, W. (1932). J. biol. Chem. 97, 359.

Schoenheimer, R. \& Breusch, F. (1933). J. biol. Chem. 103, 439.

Schoenheimer, R. \& Sperry, W. M. (1934). J.biol. Chem.106, 745.

Thomson, R. O. (1951). Biochem. J. 48, x.

\section{Vitamin A in the Kidney of the Rat}

\author{
BY EVA EDEN AND T. MOORE \\ Dunn Nutritional Laboratory, University of Cambridge and Medical Research Council
}

\section{(Received 9 November 1950)}

Johnson \& Baumann $(1947 a, b)$ reported that when rats were kept on a diet deficient in vitamin A with supplements of 35 i.u. of carotene daily, or of small doses of preformed vitamin $A$, more vitamin $A$ was accumulated in their kidneys than in their livers. With higher doses, however, the usual predominance of the liver as the main site of storage was asserted.

In a preliminary communication we have reported experiments which confirmed this interesting observation (Eden \& Moore, 1950). The purpose of the present paper is to present our results in detail. Since Moore \& Sharman (1950) have recently found that the distribution of vitamin A between the liver and kidneys is influenced by sex our results on male and female animals will be considered separately.

\section{EXPERIMENTAL}

In most of our experiments groups of young piebald rats, weaned from mothers receiving an adequate mixed diet, were given for 4-7 weeks a diet of casein $20 \%$, sugar $45 \%$, dried brewer's yeast $10 \%$, minerals $5 \%$ and either lard (groups 1, 2, 3,6 and 7 in Table 1) or cod liver oil $20 \%$ (groups 5 and 8). The diet with lard, and without supplements of vitamin A, caused the disappearance of vitamin A from both the liver and kidneys within 5 weeks. Groups 1-3 received daily supplements of 20 i.u. of synthetic vitamin A acetate, which was kindly supplied by Roche Products Ltd. The animals of groups 6 and 7 received only a single dose of 2000 i.u. of vitamin A acetate $48 \mathrm{hr}$. before they were killed. The cod liver oil supplied to groups 5 and 8 was of a high class medicinal grade containing about 800 i.u./g. of vitamin A, and was mixed freshly each day with the solid components of the diet. The rats in group 4 were adult males, about 1 year old, which had been used for breeding purposes; their diet had been made up of bread, milk, meat and vegetables, with occasional doses of cod liver oil.

It may be mentioned that the rats in groups 1, 2, 5, 6 and 8 received a diet lacking in vitamin $\mathbf{E}$. The animals in groups 3 and 7 were each dosed with $2 \mathrm{mg}$. of $( \pm)$ - $\alpha$-tocopheryl acetate weekly, while those in group 4 had derived adequate supplies from their mixed diet. Although it is known that vitamin $\mathbf{E}$ may influence the storage of vitamin $\mathbf{A}$ in some 